\title{
Transfer Hydrogenation of Ketones Using Pyridine-Aminoalcohol Ligands
}

\author{
Serpil Denizaltı* \\ Ege University, Department of Chemistry, 35100, Bornova-İzmir/Turkey, Phone: +90 232311 1780, e-mail: \\ serpil.denizalti@ege.edu.tr
}

Received: 2 January 2018

Accepted: 20 March 2018

DOI: $10.18466 /$ cbayarfbe. 373599

\begin{abstract}
Pyridine-aminoalcohol ligands were synthesized and evaluated as catalyst generated in situ from $\mathrm{RuCl}_{2}\left(\mathrm{PPh}_{3}\right)_{3}$ for transfer hydrogenation of aromatic ketones. It was found that the ligand $\mathbf{I}$ was more active than II.

Keywords: Transfer hydrogenation; Aminoalcohol; Ruthenium
\end{abstract}

\section{Introduction}

Transfer hydrogenation (TH) of aromatic ketones is one of the most significant reactions in the synthesis of pharmaceutics. Although direct hydrogenation is more widely applied, TH is a preferable method because of the ready availability of hydrogen donor and low cost of reducing agents [1-6]. Over the last two decades, various aminoalcohol ligands (I-III) have been tested in many reactions, such as the addition of diethyl zinc to aldehydes [7,8] Friedel-Crafts alkylation of indoles [9], Henry reaction [10] and transfer hydrogenation of ketones [11-15]. Brunner and co-workers also prepared pyridine-aminoalcohol ligands (IV-V), which contain phenolic hydroxyl group and investigated their catalytic activities in TH (Figure 1)[16-18].<smiles>CCC(CO)NCc1ccccn1</smiles><smiles>CC(C)C(CO)NCc1ccccn1</smiles><smiles>NC(CO)c1ccccc1</smiles><smiles>Cc1cc([18O])c(O)c(CNC(C)c2ccccn2)c1</smiles><smiles>Oc1ccc2ccccc2c1-c1c(NCc2ccccn2)ccc2ccccc12</smiles>

IV

v

Figure 1. Aminoalcohol ligands.

As far as I know, these ligands (I, II) have not been utilized in ATH, even though they had been synthesized before [7-9]. In the study reported here, two pyridineamino alcohol ligands bearing alkylgroup at $\alpha$-positon were synthesized to apply them for $\mathrm{TH}$ reaction of aromatic ketones.

\section{Materials and Methods}

All reactions were performed under argon atmosphere. Pyridine-aminoalcohols (I, II) were synthesized according to the literature $[7,8,17,19] .{ }^{1} \mathrm{H}$ NMR $(400$ $\mathrm{MHz})$ and ${ }^{13} \mathrm{C}$ NMR (100 MHz) spectra were measured using Varian 400 spectrometer with $\mathrm{CDCl}_{3}$ as the solvent. Elemental analyses were performed with Perkin Elmer 2400 elemental analyser. The yields of the catalytic products were determined by GC analyses using Thermo-Finnigan gas chromatography with HP-5 capillary column.

\subsection{General procedure for the synthesis of I,II}

The solution of 2-pyridinecarboxaldehyde (1.0 g, 9.34 $\mathrm{mmol})$ and aminoalcohol $(9.34 \mathrm{mmol})$ in dry toluene $(10 \mathrm{~mL})$ in a flask was heated to reflux for overnight. After cooling, toluen was removed in vacuum. The residue was dissolved in $\mathrm{MeOH}$. $\mathrm{NaBH}_{4}$ was slowly added to the mixture. After stirring at room temperature for $1 \mathrm{~h}$, the mixture was refluxed overnight. The solvent was removed. The residue was dissolved in $\mathrm{CH}_{2} \mathrm{Cl}_{2}$ and extracted with $\mathrm{H}_{2} \mathrm{O}$. The organic layer was dried over $\mathrm{Na}_{2} \mathrm{SO}_{4}$, filtered and then concentrated in vacuo.

I: ${ }^{1} \mathrm{H}$ NMR ( $\left(400 \mathrm{MHz}, \mathrm{CDCl}_{3}\right.$, TMS, $\left.25^{\circ} \mathrm{C}, \mathrm{ppm}\right): 0.95$ $\left(3 \mathrm{H}, \mathrm{t}, J=7.5 \mathrm{~Hz}, \mathrm{CH}_{3} \mathrm{CH}_{2}\right), 1.44-1.57(2 \mathrm{H}, \mathrm{m}$, $\left.\mathrm{CH}_{3} \mathrm{CH}_{2}\right), 2.59-2.65\left(1 \mathrm{H}, \mathrm{m}, \mathrm{NCHCH}_{2} \mathrm{OH}\right), 3.35-3.39$ $\left(1 \mathrm{H}, \mathrm{m}, \mathrm{NCHCH}_{2} \mathrm{OH}\right), 3.62-3.66(1 \mathrm{H}, \mathrm{m}$, $\left.\mathrm{NCHCH}_{2} \mathrm{OH}\right), 3.93\left(2 \mathrm{H}, \mathrm{dd}, J=14.6 \mathrm{~Hz}, \mathrm{PyCH}_{2} \mathrm{NH}\right)$, 7.14-7.18 (1 H, m, Py- $H)$, 7.24-7.26 (1 H, m, Py- $H)$, 7.61-7.65 (1 H, m, Py-H), 8.53-8.54 (1 H, m, Py-H). ${ }^{13} \mathrm{C}$ NMR $\left(100 \mathrm{MHz}, \mathrm{CDCl}_{3}\right.$, TMS, $\left.25{ }^{\circ} \mathrm{C}, \mathrm{ppm}\right): 10.1$ 
$\left(\mathrm{CH}_{3} \mathrm{CH}_{2}\right), 23.5\left(\mathrm{CH}_{3} \mathrm{CH}_{2}\right), 51.8 \quad\left(\mathrm{PyCH}_{2} \mathrm{NH}\right), 59.7$ $\left(\mathrm{NCHCH}_{2} \mathrm{OH}\right), 62.4 \quad\left(\mathrm{NCHCH}_{2} \mathrm{OH}\right), 121.3 ; 121.8$; 136.3; 148.0; 159.7 (Рy-C). Anal. Calc. for $\mathrm{C}_{10} \mathrm{H}_{16} \mathrm{~N}_{2} \mathrm{O}$ : C, 66.63; H, 8.95; N, 15.54. Found: C, 66.59; H, 8.92; $\mathrm{N}, 15.51$

II: ${ }^{1} \mathrm{H}$ NMR (400 $\left.\mathrm{MHz}, \mathrm{CDCl}_{3}, \mathrm{TMS}, 25{ }^{\circ} \mathrm{C}, \mathrm{ppm}\right)$ : $0.91,0.99\left(6 \mathrm{H}, \mathrm{d}, J=6.8 \mathrm{~Hz}, \mathrm{CH}\left(\mathrm{CH}_{3}\right)_{2}\right), 1.79-1.88$ (1 $\left.\mathrm{H}, \mathrm{m}, \mathrm{CH}\left(\mathrm{CH}_{3}\right)_{2}\right), 2.45-2.50\left(1 \mathrm{H}, \mathrm{m}, \mathrm{NCHCH}_{2} \mathrm{OH}\right)$, 3.42-3.47 (1 H, m, $\left.\mathrm{NCHCH}_{2} \mathrm{OH}\right), 3.65-3.69(1 \mathrm{H}, \mathrm{m}$, $\left.\mathrm{NCHCH}_{2} \mathrm{OH}\right), 3.89-4.04(2 \mathrm{H}, \mathrm{dd}, J=14.8 \mathrm{~Hz}$, $\left.\mathrm{PyCH}_{2} \mathrm{NH}\right), 7.15-7.19(1 \mathrm{H}, \mathrm{m}, \mathrm{Py}-\mathrm{H}), 7.25-7.27(1 \mathrm{H}$, m, Py- $H)$, 7.62-7.66 (1 H, m, Py- $H)$, 8.54-8.55 (1 H, m, Py-H). ${ }^{13} \mathrm{C}$ NMR $\left(100 \mathrm{MHz}, \mathrm{CDCl}_{3}\right.$, TMS, $\left.25^{\circ} \mathrm{C}, \mathrm{ppm}\right)$ : 18.7,19.4 $\left.\left.\left(\mathrm{CH}_{3}\right)_{2} \mathrm{CH}\right), \quad 29.4 \quad\left(\mathrm{CH}_{3}\right)_{2} \mathrm{CH}\right), \quad 52.4$ $\left(\mathrm{PyCH}_{2} \mathrm{NH}\right), 61.3\left(\mathrm{NCHCH}_{2} \mathrm{OH}\right), 64.7\left(\mathrm{NCHCH}_{2} \mathrm{OH}\right)$, 122.0; 122.3; 136.7; 148.9; 159.9 (Py-C). Anal. Calc. for $\mathrm{C}_{11} \mathrm{H}_{18} \mathrm{~N}_{2} \mathrm{O}$ : C, 68.01; H, 9.34; N, 14.42. Found: C, $67.95 ; \mathrm{H}, 9.30 ; \mathrm{N}, 14.38$.

\subsection{General procedure for the transfer} hydrogenation reaction [4]

To a two-necked flask was added $\mathrm{RuCl}_{2}\left(\mathrm{PPh}_{3}\right)_{3}(4$ mol\%), pyridine-aminoalcohol ligand (I or II) (4 $\mathrm{mol} \%$ ), ketone (1 mmol) and isopropylalcohol (IPA) (5 $\mathrm{ml})$. Then, $\mathrm{KO}{ }^{t} \mathrm{Bu}(1 \mathrm{mmol})$ was added, and the solution was heated at $80^{\circ} \mathrm{C}$ under argon atmosphere. After $6 \mathrm{~h}$, the solvent was removed in vacuum. The residue was dissolved in hexane-ethylacetate (1:1) mixture and filtered. The yields were determined by GC.

\section{Results and Discussion}

Pyridine-aminoalcohol ligands (I,II) were prepared by two-step reactions, according to the previously published procedure (Figure 2). The ligands (I,II) were characterized by NMR analyses and the NMR values were consistent with the literature (Figure 3) $[7,8,17,19,20]$.

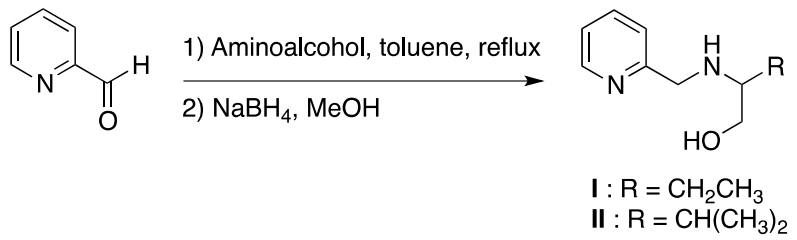

Figure 2. Synthesis of pyridine-aminoalcohol ligands (I, II).

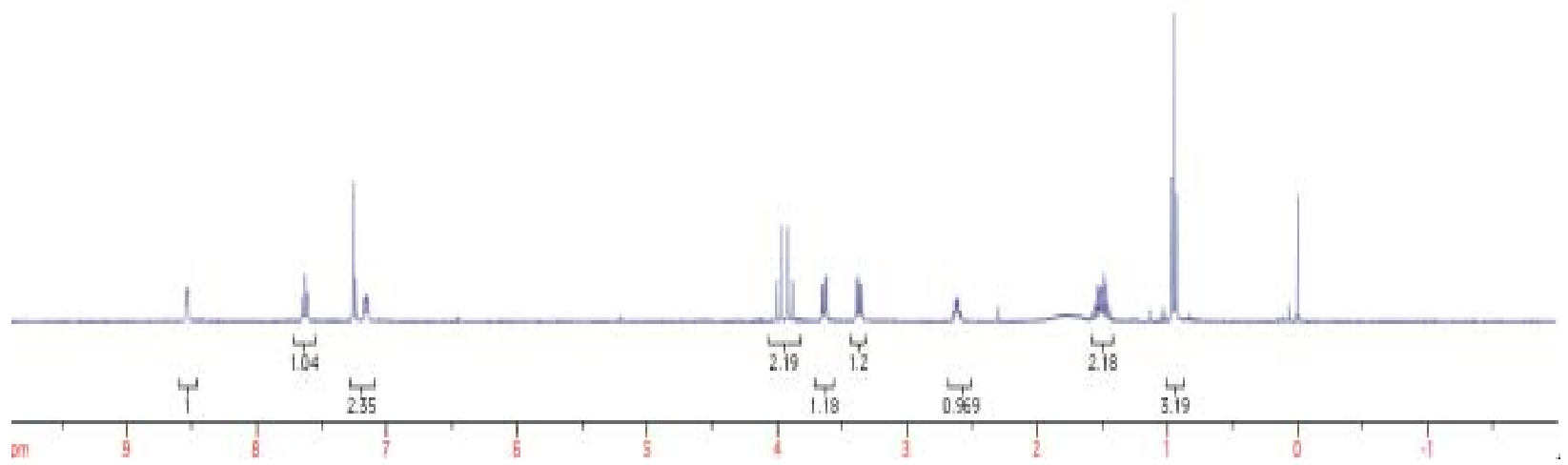

(a)
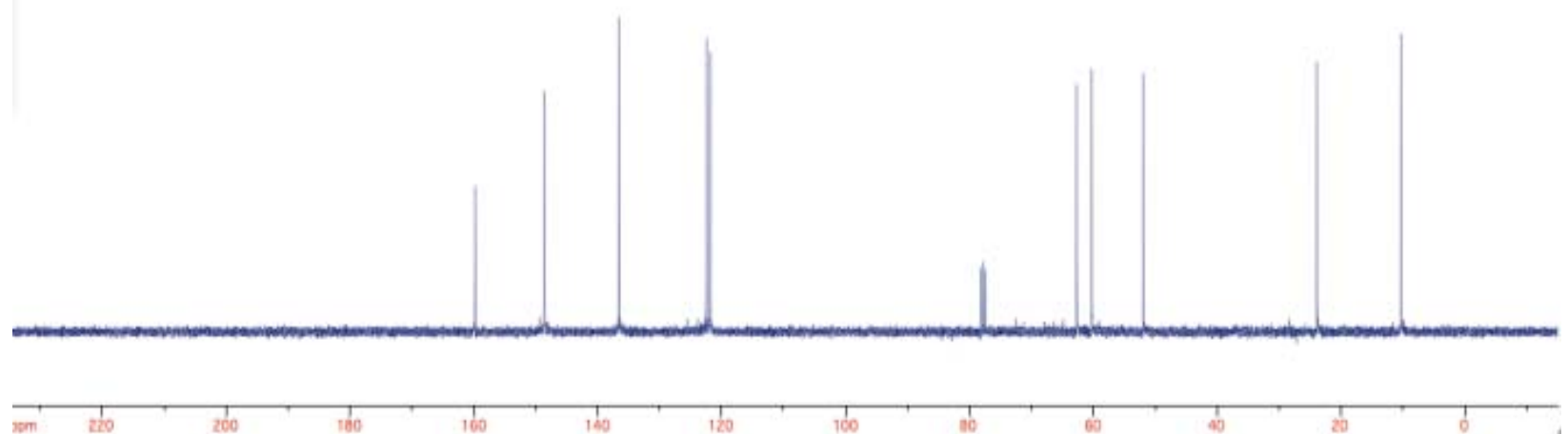

(b) 


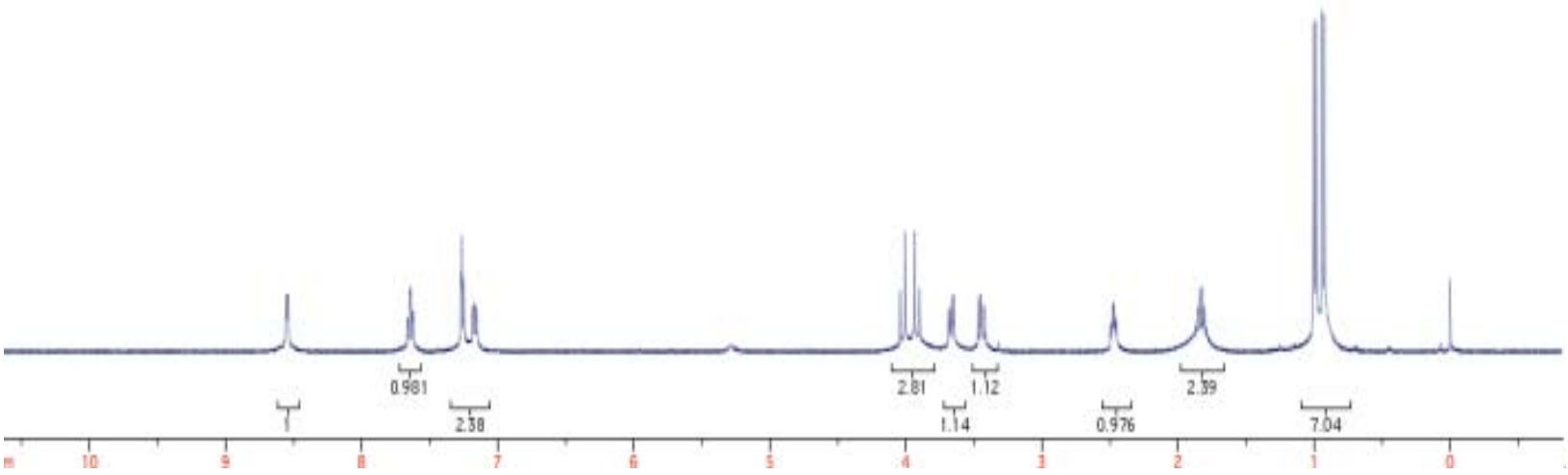

(c)
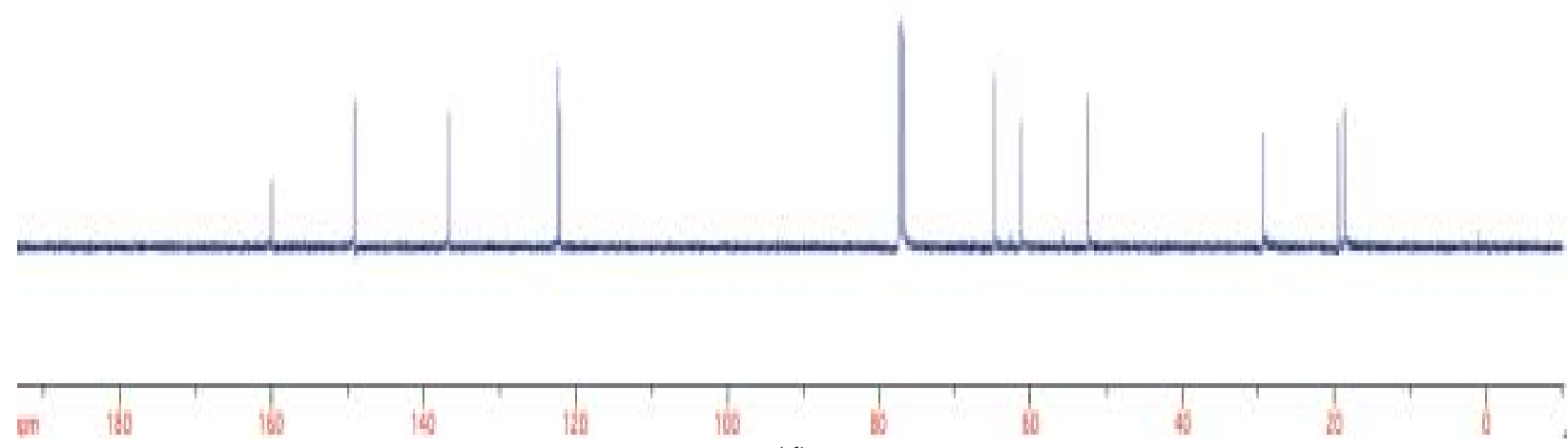

(d)

Figure 3. ${ }^{1} \mathrm{H}$ and ${ }^{13} \mathrm{C}$ NMR spectra of pyridine-aminoalcohol ligands (a,b) I, (c,d) II.

The synthesized ligands were evaluated in the $\mathrm{TH}$ reaction of aromatic ketones. The catalytic experiments were performed using \% $4 \mathrm{~mol}$ ligand and \% $4 \mathrm{~mol}$ $\mathrm{RuCl}_{2}\left(\mathrm{PPh}_{3}\right)_{3}$ as ruthenium source at $80{ }^{\circ} \mathrm{C}$ in IPA. The results were shown on Table 1.

Table 1. Transfer hydrogenation $(\mathrm{TH})$ of ketones using the ligand I, II.<smiles>[R]c1ccccc1C(=O)Sc1cccc(C(C)O)c1</smiles>

\begin{tabular}{|c|c|c|c|}
\hline Entry & Ketone & Ligand & Yield (\%) \\
\hline 1 & \multirow{2}{*}{$\mathrm{PhCOCH}_{3}$} & I & 80 \\
\cline { 1 - 2 } \cline { 3 - 4 } & & II & 62 \\
\hline
\end{tabular}<smiles>CC(O)c1ccccc1</smiles>

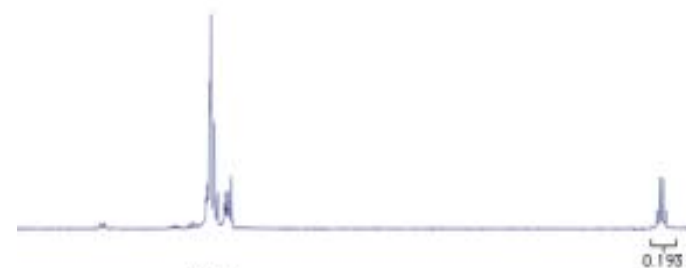

\begin{tabular}{|c|c|c|c|}
\hline 3 & \multirow{2}{*}{$4^{\prime}-\mathrm{Cl}-\mathrm{PhCOCH}_{3}$} & I & 91 \\
\hline 4 & & II & 90 \\
\hline 5 & \multirow{2}{*}{$4^{\prime}-\mathrm{MeO}-\mathrm{PhCOCH}_{3}$} & $\mathbf{I}$ & 61 \\
\hline 6 & & II & 50 \\
\hline 7 & \multirow{2}{*}{ 2'-Cl- $\mathrm{PhCOCH}_{3}$} & $\mathbf{I}$ & 99 \\
\hline 8 & & II & 99 \\
\hline 9 & \multirow{2}{*}{$2^{\prime}-\mathrm{MeO}-\mathrm{PhCOCH}_{3}$} & I & 87 \\
\hline 10 & & II & 72 \\
\hline
\end{tabular}

As can be seen from Table 1, moderate to good yields (6199\%) are obtained. The electron-with drawing substituents on acetophenone gave rise to better yield (up to 90\%) within $6 \mathrm{~h}$ at $80^{\circ} \mathrm{C}$. A comparison of para-substituted ketones with the ortho-substituted ones, para position gave lower yields. 
<smiles>COc1ccc(C(C)O)cc1</smiles>

\section{$\mathrm{OH}$}

$\mathrm{MeO}$
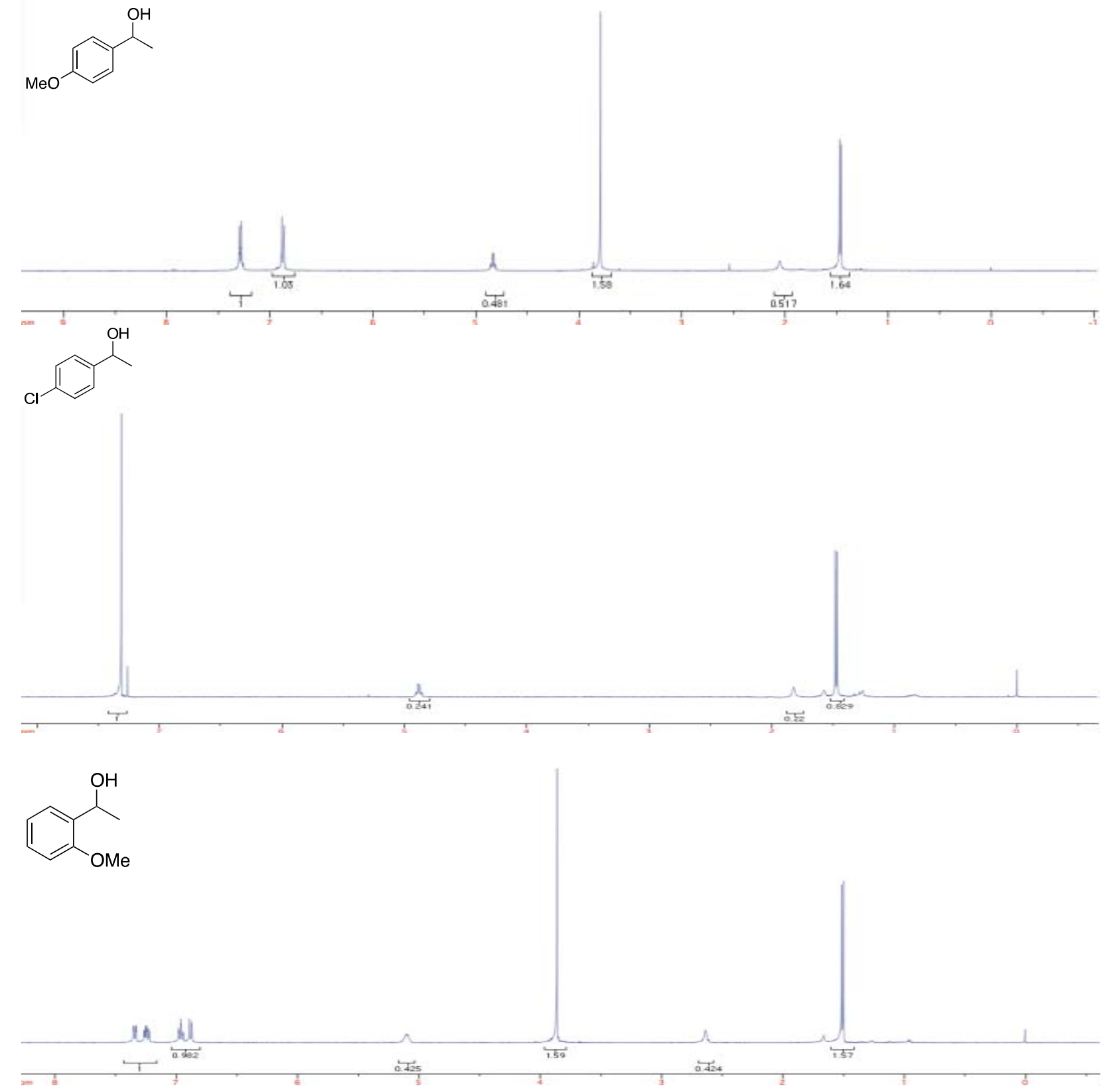<smiles>CC(O)c1ccccc1Cl</smiles>

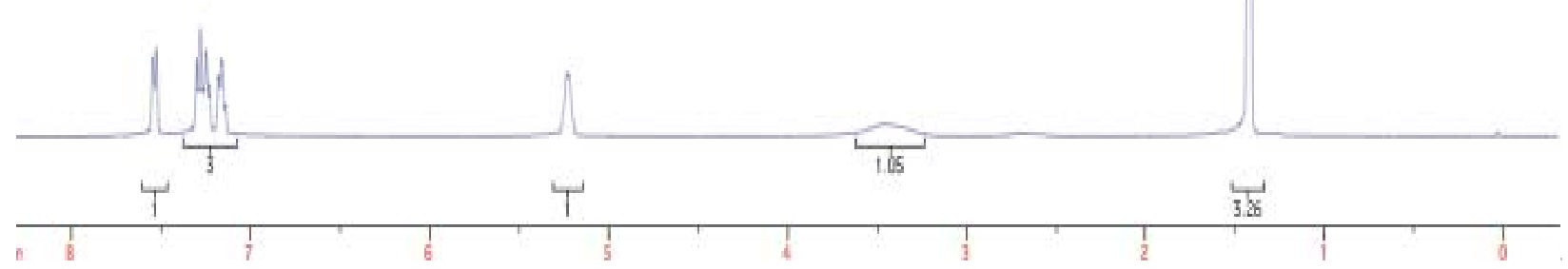

Figure 4. ${ }^{1} \mathrm{H}$ NMR spectra of the catalytic products. 


\section{Conclusion}

Two pyridine-aminoalcohol ligands were prepared and tested as catalysts for the first time in $\mathrm{TH}$ reaction. They showed good activity for aromatic ketones, and moderate to high yields were obtained. It was found that the steric effect of ligand affected the catalytic performance in $\mathrm{TH}$. Ligand I was found to be more efficient than II in transfer hydrogenation.

\section{References}

1. Hashiguchi, S, Fujii, A, Takehara, J, Ikariya, T, Noyori, R, Asymmetric Transfer Hydrogenation of Aromatic Ketones Catalyzed by Chiral Ruthenium(II) Complexes, Journal of American Chemical Society, 1995, 117, 7562-7563.

2. Ikariya, T, Blacker, A.J, Asymmetric Transfer Hydrogenation of Ketones with Bifunctional Transition Metal-Based Molecula Catalysts, Accounts of Chemical Research., 2007, 40, 1300-1308.

3. Denizaltı, S, Mercan, D, Șen, B, Gökçe, A.G, Cetinkaya, B Asymmetric Transfer Hydrogenation Reaction in Water: Comparison of Chiral Proline Amide/Amine Ruthenium(II) Complexes, Journal of Organometallic Chemistry, 2015, 779, 62 66

4. Denizaltı, S, Şen, B, Gökçe, A.G, Çetinkaya, B, Ruthenium(II) Complexes Derived from 2-phenylthiazoline-4-carboxylic acid Structure and Catalytic Activity for Transfer Hydrogenation Reaction, Applied Organometallic Chemistry, 2016, 30, 373-377.

5. Foubelo, F, Najera, C, Yus, M, Catalytic Asymmetric Transfer Hydrogenation of Ketones: Recent Advances, Tetrahedron: Asymmetry, 2015, 26, 769-790.

6. Wang, D, Astruc, D, The Golden Age of Transfer Hydrogenation, Chemical. Reviews., 2015, 115, 6621-6686.

7. Wu, Y, Yun, $\mathrm{H}, \mathrm{Wu}, \mathrm{Y}$, Ding, $\mathrm{K}$, Zhou, Y, Synthesis of $N-\alpha-$ pyridylmethyl Amino Alcohols and Application in Catalytic Asymmetric Addition of Diethylzinc to Aromatic Aldehydes, Tetrahedron: Asymmetry, 2000, 11, 3543-3552.

8. Yun, H, Wu, Y, Wu, Y, Ding, K, Zhou, Y, Chiral Ligands for Asymmetric Synthesis: Enantioselective Addition of Diethylzinc to Aromatic Aldehydes Catalyzed by Chiral $N$ - $\alpha$-pyridylmethyl Amino Alcohols, Tetrahedron Letters, 2000, 41, 10263-10266.

9. Grach, G, Dinut, A, Marque, S, Marrot, J, Gil, R, Prim, D, Enantioselective Friedel-Crafts Alkylation of Indole Derivatives Catalyzed by New $\mathrm{Yb}(\mathrm{OTf})_{3}$-pyridylalkylamine Complexes as Chiral Lewis Acids, Organic and Biomolecular Chemistry, 2011, 9, 497-503.

10. Xu, F, Lei, C, Yan, L, Tu, J, Li, G, Copper-Chiral Camphor $\beta$ Amino Alcohol Complex Catalyzed Asymmetric Henry Reaction, Chirality, 2015, 27, 761-765.
11. Deshpande, S.H, Kelkar, A.A, Gonnade, R.G, Shingote, S.K, Chaudhari, R.V, Catalytic Asymmetric Transfer Hydrogenation of Ketones Using [Ru(p-cymene $\left.\mathrm{Cl}_{2}\right]_{2}$ with Chiral Amino Alcohol Ligands, Catalysis Letters, 2010, 138, 231-238.

12. Pastó, M, Riera, A, Pericàs, M.A, Fine-Tuning of Modular Amino Alcohol Ligands for the Enantioselective Transfer Hydrogenation of Ketones, European Journal of Organic Chemistry, 2002, 2337. 2341

13. Han, M.-L, Hub, X.-P, Huang, J.-D, Chen, L.-G, Zheng, Z, New Chiral Amino Alcohol Ligands Derived from 1-phenylethylamine for Efficient Ru-Catalyzed Asymmetric Transfer Hydrogenation, Tetrahedron: Asymmetry, 2011, 22, 222-225.

14. Alza, E, Bastero, A, Jansata, S, Pericàs, M.A, Aqueous Asymmetric Transfer Hydrogenation Using Modular Hydrophobic Aminoalcohols, Tetrahedron: Asymmetry, 2008, 19, 374-378.

15. Wang, X, Xu, L, Xiong, F, Wu, Y, Chen, F, A New CostEffective Ru-Chloramphenicol Base Derivative Catalyst for the Asymmetric Transfer Hydrogenation/Dynamic Kinetic Resolution of NBoc $\alpha$-amino- $\beta$-ketoesters and Its Application to the Synthesis of the Chiral Core of Vancomycin, RSC Advances, 2016, 6, 37701-37709.

16. Brunner, H, Henning, F, Weber, M, Enantioselective Catalysis Part 143: Astonishingly High Enantioselectivity in the Transfer Hydrogenation of Acetophenone with 2-propanol using $\mathrm{Ru}$ Complexes of the Schiff Base Derived from (S)-2-amino-2_hydroxy-1,1_-binaphthyl (NOBIN) and 2-pyridinecarbaldehyde, Tetrahedron: Asymmetry, 2002, 13, 37-42.

17. Brunner, H, Niemetz, M, Enantioselective Catalysis CXLI [1] Tridentate Ligands with 1-(pyridin-2-yl)ethylamine as Chiral Building Block in the Enantioselective Transfer Hydrogenation of Acetophenone, Monatshefte für Chemie, 2002, 133, 115-126.

18. Brunner, H, Henning, F, Enantioselective Catalysis. Part 156 [1] Ruthenium Procatalysts and 2-Pyridinealdehyde $=(\mathrm{S})-\mathrm{NOBIN}$ Derived Cocatalysts in the Transfer Hydrogenation of Acetophenone with 2-Propanol, Monatshefte für Chemie, 2004 $135,885-897$

19. Ray, A, Boyle, S.M, In Silico Screening Method for Identifying Ligands for Odor Receptors and Olfactory Neurons for Use as Repellents in Traps or Other Media, The Patent Cooperation Treaty (PCT) International Application, 2011, WO 2011130726 A2 20111020

20. Strong, E.T.J., Cardile, S.A, Brazeau, A.L, Jennings, M.C, McDonald, R, Jones, N.D, Chiral, Hemilabile Palladium(II) Complexes of Tridentate Oxazolidines, Including C2-Symmetric "Pincers", Inorganic Chemistry, 2008, 47, 10575-10586. 